\title{
Boranils: Versatile Multifunctional Organic Fluorophores for Innovative Applications
}

\author{
Julien Massue $^{1, *(\mathbb{D} \text {, Denis Jacquemin }}{ }^{2, *}$ and Gilles Ulrich ${ }^{1, *}$ \\ 1 Institut de Chimie et Procédés pour l'Energie, l’Environnement et la Santé (ICPEES), Equipe Chimie \\ Organique pour la Biologie, les Matériaux et l'Optique (COMBO), UMR CNRS 7515, Ecole Européenne de \\ Chimie, Polymères et Matériaux (ECPM), 25 Rue Becquerel, CEDEX 02, 67087 Strasbourg, France \\ 2 CEISAM Lab-UMR 6230-CNRS, University of Nantes, 44000 Nantes, France \\ * Correspondence: massue@unistra.fr (J.M.); Denis.Jacquemin@univ-nantes.fr (D.J.); gulrich@unistra.fr (G.U.)
}

check for updates

Citation: Massue, J.; Jacquemin, D.; Ulrich, G. Boranils: Versatile Multifunctional Organic Fluorophores for Innovative Applications. Organics 2021, 2, 365-375. https://doi.org/10.3390/ org2040020

Academic Editor: Wim Dehaen

Received: 26 August 2021

Accepted: 30 September 2021

Published: 12 October 2021

Publisher's Note: MDPI stays neutral with regard to jurisdictional claims in published maps and institutional affiliations.

Copyright: (c) 2021 by the authors. Licensee MDPI, Basel, Switzerland. This article is an open access article distributed under the terms and conditions of the Creative Commons Attribution (CC BY) license (https:// creativecommons.org/licenses/by/ $4.0 /)$.

\begin{abstract}
Multifunctional stimuli-responsive fluorophores showing bright environment-sensitive emissions have fueled intense research due to their innovative applications in the fields of biotechnologies, optoelectronics, and materials. A strong structural diversity is observed among molecular materials, which has been enriched over the years with a growing responsiveness to stimuli. Boron dipyrromethene (BODIPY) dyes have long been the flagship of emissive boron complexes due to their outstanding properties until a decade ago when analogues based on $\mathrm{N}^{\wedge} \mathrm{O}, \mathrm{N}^{\wedge} \mathrm{N}$, or $\mathrm{N}^{\wedge} \mathrm{C} \pi$-conjugated chelates emerged. The finality of developing borate dyes was to compensate for BODIPYs' lack of solid-state fluorescence and small Stokes shifts while keeping their excellent optical properties in solution. Among them, the borate complexes based on a salicylaldimine ligand, called by the acronym boranils appear as the most promising, owing to their facile synthesis and dual-state emission properties. Boranil dyes have proven to be good alternatives to BODIPY dyes and have been applied in applications such as bioimaging, bioconjugation, and detection of biosubstrates. Meanwhile, ab initio calculations have rationalized experimental results and provided insightful feedback for future designs. This review article aims at providing a concise yet representative overview of the chemistry around the boranil core with the subsequent applications.
\end{abstract}

Keywords: boranils; boron complexes; fluorescence spectroscopy; dyes and pigments; TD-DFT calculations

\section{Introduction}

The current research aiming to engineer new fluorescent dyes is highly dynamic and primarily arises from fruitful collaborations between chemists, physicists, and biologists, continuously fueled by the applications of molecular probes in many fields, e.g., biomedical imaging, analysis, sensing, detection, materials science, etc. In particular, scientific innovation has led to major developments in the field of organic electronics including organic light-emitting diodes (OLED), photovoltaic cells, solar energy concentrators, or transistors [1-3]. In parallel, fluorescent emitters have contributed to the advancement of biotechnologies, mainly in biosensing and bioimaging [4-6]. Meanwhile, intense fundamental research has taken place aimed at designing original molecular structures with exceptional chemical, photochemical, and thermal stabilities, allowing prolonged exposure to harsh conditions of light and heat. Numerous families of dyes have been engineered with that purpose in mind, including polycyclic aromatic hydrocarbon (PAHs) [7], such as pyrene, tetracene, pentacene, perylene, porphyrins [8,9], coumarins [10], xanthenes [11] such as rhodamines or fluorescein, cyanines [12], squaraines [13], and peryleneimides [14]. One of the most popular families of organic dyes in recent decades is undoubtedly constituted of 4,4'-difluoro-4-bora-3a,4a-diaza-s-indacene derivatives, also known as BODIPY dyes [15-18]. Synthetic efforts notably allowed fine-tuning of the emission color, up to the near infra-red (NIR) and replacement of the fluoro ligands on boron by functionalized 
alkynes [19]. BODIPY dyes display outstanding photophysical properties, such as narrow absorption and emission bands, high molar absorption coefficients, and fluorescence quantum yields frequently reaching unity in solution. They also show remarkable chemical and photochemical stability. Nonetheless, they typically display weak emission intensity in the solid-state, as amorphous powders or crystals or even being doped in rigid matrixes owing to a flat scaffold, leading to tight packing and strong intermolecular interactions in the solid-state. [13] One strategy used to circumvent this drawback is to introduce sterically hindered substituents at the periphery of the BODIPY core to alleviate molecular aggregation [13]. This flat, rigid core is also at the origin of a strong overlap between absorption and emission band, i.e., very small Stokes shifts, leading to auto reabsorption phenomena and artificial decrease of luminescence intensity. In contrast, strong solid-state fluorescence can be observed in the case of dyes displaying excited-state intramolecular proton transfer (ESIPT) processes, where a tautomeric equilibrium leads to a major reorganization of the molecular scaffold in the excited-state and a subsequent increase of Stokes shifts [20,21].

The search for novel fluorescent scaffolds remains a challenging target in order to enrich the field of heterocyclic chemistry with expedite syntheses and easily functionalizable scaffolds. Among these derivatives, many are based on the use of a central four-coordinate boron (III) atom with the view to conveniently lock $\mathrm{N}^{\wedge} \mathrm{N}$ and $\mathrm{N}^{\wedge} \mathrm{O}$ ligands, flatten the structures, and increase conjugation and molecular rigidity [22]. The ligands are typically charged through deprotonation of phenol- or pyrrole-based structures, and two additional anions ( $\mathrm{F}$ or Aryl) on the boron center ensure global neutrality of the resulting dyes. Over the years, many B (III) complexes have been engineered, highly inspired by the fantastic luminescent properties of BODIPY dyes in solution [23,24]. The ultimate goals behind these chemical engineering studies are to (i) expedite and upscale multi-step syntheses, (ii) decrease spectral overlap between absorption and emission, and (iii) increase solid-state emission intensity while retaining the outstanding optical characteristics of BODIPY dyes in solution. Among these dyes, borate complexes based on an aniline-imine or salicylaldimine ligand, also known as boranils, have rapidly emerged as the most interesting examples owing to their facile multi-gram scale synthesis and the fine-tuning of their emission properties (Figure 1).

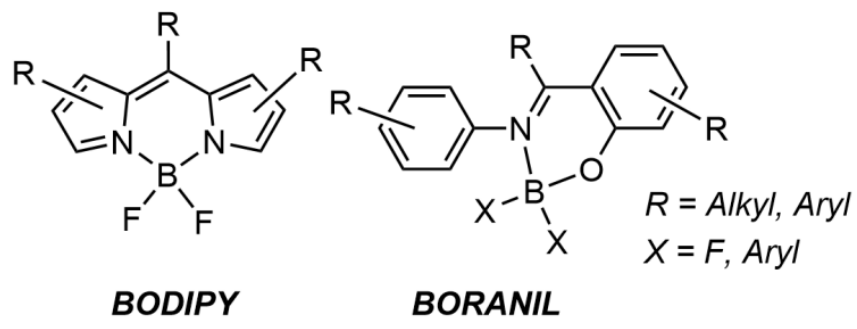

Figure 1. Structures of BODIPY and boranil dyes.

This mini-review is focused on providing a short but extensive overview of the chemistry of boranils developed up to now, through the description of reported examples. The post-functionalization, optical properties in solution and in the solid state will be discussed along with potential applications and theoretical aspects. Other recent elegant examples describe fluorescent boron complexes called boranyls, including amide-based difluoroboranyls $[23,24]$, but these dyes do not fall within the scope of this mini-review.

\section{Synthesis, Derivatizations, and Applications}

Typical synthesis of boranils complexes takes place in two steps from commercially available starting materials, i.e., substituted anilines and salicylaldehydes (Figure 2). Preparation of the anil derivatives is highly straightforward and can be easily achieved by refluxing reactants in ethanol with the possibility to add trace amounts of $p$-TsOH. During the course of the reaction the target imines typically precipitate pure out of the crude 
reaction mixture within one to three hours. Subsequent trivalent boron complexation using excess of $\mathrm{BF}_{3}$ is performed. $\mathrm{Et}_{2} \mathrm{O}$ under basic conditions (DIEA or $\mathrm{NEt}_{3}$ ) leads to pure boranils after purification on silica chromatography. The completion of the reaction can be readily monitored by ${ }^{1} \mathrm{H}$ NMR spectroscopy, the loss of the downfield signal between 12 and $15 \mathrm{ppm}$ due to the $\mathrm{H}$-bonded phenolic proton being distinctive. It is worth mentioning that in boranils complexes, a typical coupling of the imine proton to the ${ }^{11} \mathrm{~B}$ center is observed, leading to the appearance of a broad quartet [25-30]. Additionally, enhanced Stokes shifts, $\Delta_{\mathrm{SS}}$ are usually observed ( $\Delta_{\mathrm{SS}}$ up to $9000 \mathrm{~cm}^{-1}$ ), as compared to BODIPY dyes which contribute to lower detrimental reabsorption processes [25-30].

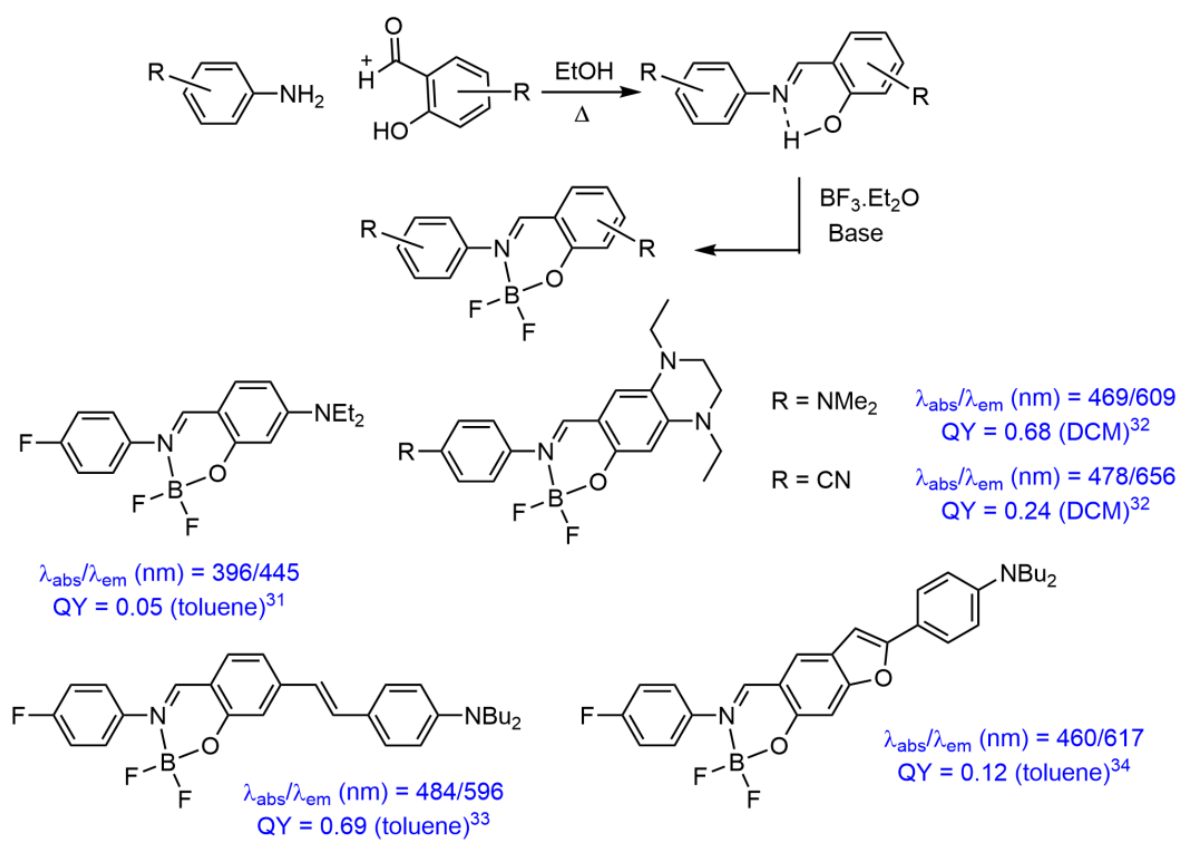<smiles>CCN(CC)c1ccc2c(c1)OP(F)(F)(F)N(c1ccc(N3Cc4ccc(N(CC)CC)cc4OP3(F)(F)F)cc1)C2</smiles>

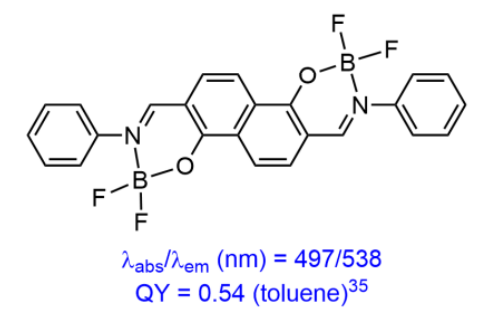

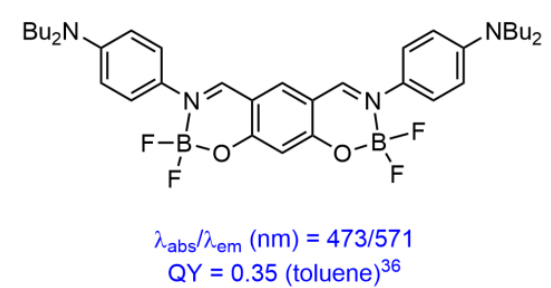

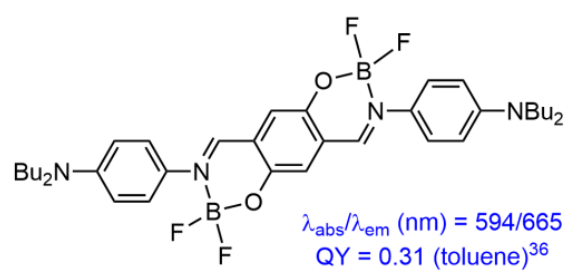

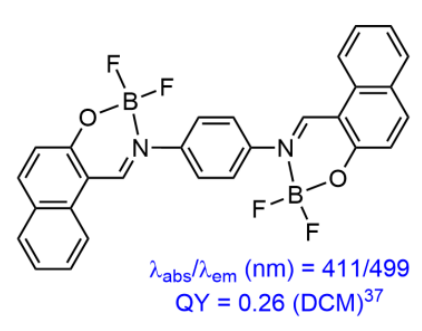

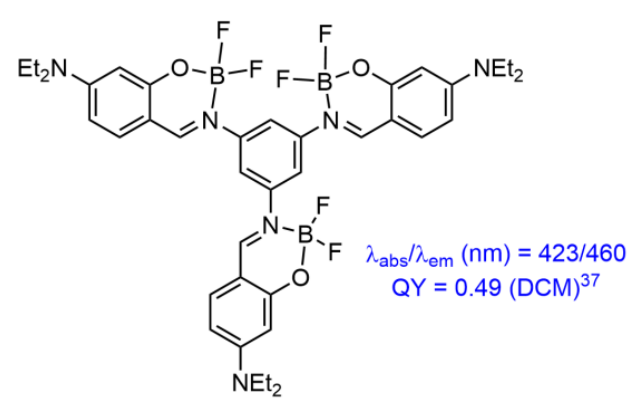

Figure 2. Synthesis and reported examples of Boranil structures [31-37]. 
As shown in Figure 2, a wide panel of boranils structures has been reported over the years, with a strong emphasis on fine-tuning the emission color over the whole visible range, while maintaining a strong emission intensity both in solution and in the solidstate [31-37]. Of particular similarity between the major of fluorescent derivatives reported so far is the presence of a dialkylamino moiety on the phenolic side of the dyes, as a way to further stabilize the corresponding boron complexes in solution. Simple boranils dyes with diethylamino moiety display UV-centered fluorescence emission $\left(\lambda_{\mathrm{em}}=445 \mathrm{~nm}\right)$ with a weak quantum yield (QY) of 0.05 [31]. This feature was ascribed to a twisted intramolecular charge transfer (TICT), among other molecular motions occurring in the excited-state leading to a heavy quenching fluorescent emission [38]. One strategy applied to enhance these parameters is to introduce rigid electrodonating groups on the phenolic side such as julolidine [39] or 1,2,3,4-tetrahydroquinoxaline [32]. The latter strategy appeared to be particularly fruitful, as strong red emission $\left(\lambda_{\mathrm{em}}=656 \mathrm{~nm}, \mathrm{QY}=0.24\right)$ was recorded in this case. Another synthetic strategy commonly employed to redshift emission is to induce a long-range intramolecular charge transfer (ICT) emission by increasing the $\pi$-conjugated spacer between donor and acceptor. Notably, an extended 2-(6'-hydroxy5 -benzofuryl) scaffold triggered redshifted fluorescence emission with a pronounced fluorosolvatochromism character, a feature typical of ICT processes [34]. A second example displayed a $\pi$-extended core involving a styryl spacer [33]. This boranil complex showed unprecedented fluorosolvatochromic behavior with a maximum emission wavelength spanning the entire visible range up to the near-infrared (NIR). The facile synthetic protocol employed for the preparation of boranils dyes can be straightforwardly extended to the formation of di- and trinuclear B (III) complexes [31,35-37]. In particular, a simple dinuclear boranil complex with a central phenyl linker stiffened the structured, as evidenced by a QY of 0.90 [31]. More sophisticated examples involve a central naphthalene backbone leading to important bathochromic shifts in emission, up to $683 \mathrm{~nm}$ [35]. An extensive series of dyes based on this scaffold allowed a fine-tuning of the photophysical properties, as compared to simply substituted boranils dyes, with strong QY values, up to $83 \%$. It is worth noting that the vast majority of boranil dyes display sizeable emission in the solid-state [36].

Fluorescent dyes containing several B (III) centers are reported to be advantageous over isolated dyes owing to an enhancement of the luminescence intensity and increase of molar absorption coefficients [40-42]. Additionally, functionalization of multiple boron fragments by sterically hindered substituents can prevent detrimental aggregates in the solid-state. With a variation on the number of boranil units and the position of functionalization, several polyboranils derivatives were developed allowing for the fine modulation of the photophysical properties. Functionalization at the boron center was also achieved by the introduction of $\mathrm{B}(\mathrm{Ar})_{3}$ in lieu of archetypical $\mathrm{BF}_{3}$, usually present in boranil structures [25-30]. The presence of arenes contributes not only to the tuning the emission color but also to the improvement of the chemical stability. A marked decrease of ICT processes is also observed, as compared to their fluoride analogs [43,44].

The chemical stability of these appealing boranil dyes was further evidenced by the possibility of postfunctionalization of the molecular core, as exemplified in Figure 3 [45]. Notably, hydrogenation reaction allowed selective reduction of the nitro group without reducing the imino fragment. Amino-functionalized boranil synthon was subsequently further utilized in a range of derivatization reactions, including the preparation of boranil dyes with thiocyanate functional group. This thiocyanate-functionalized dye can be used to label lysine residues of Bovine Serum Albumine (BSA) protein, resulting in thiourea linked dye-protein assembly. 


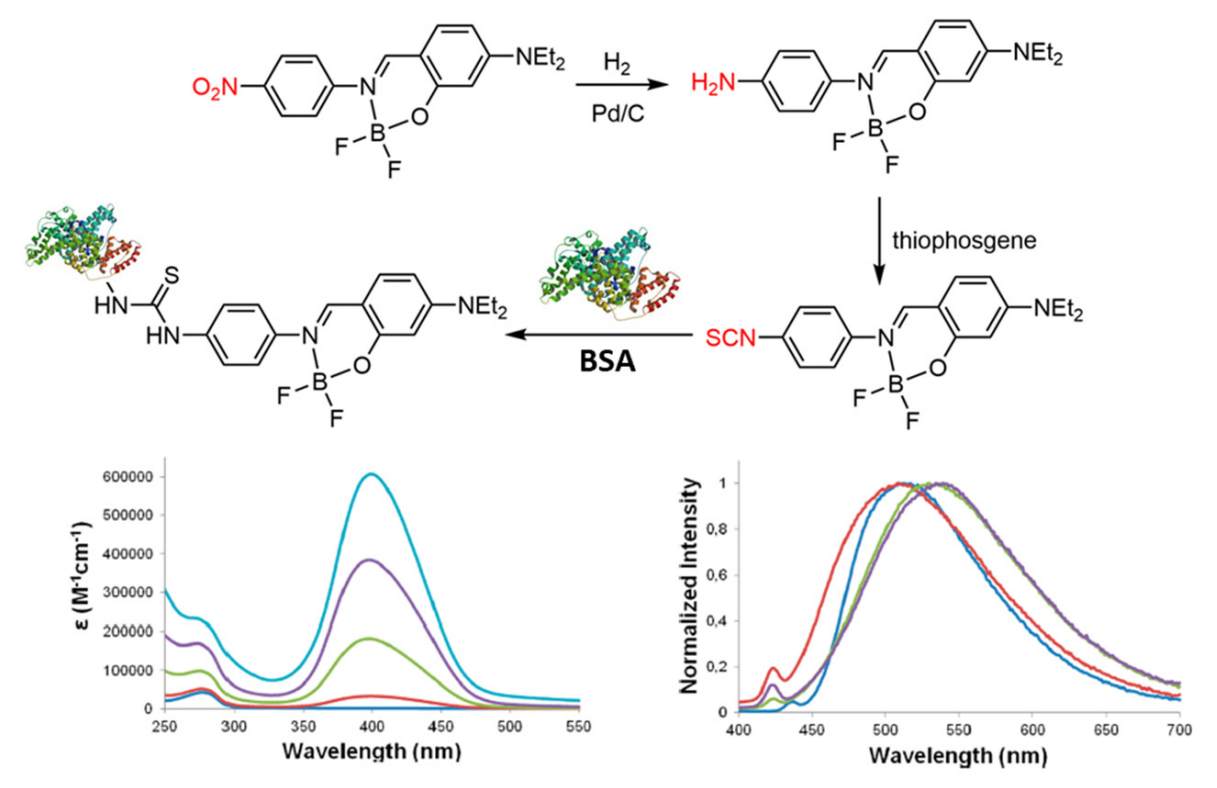

Figure 3. Postfunctionalization on the boranils core and application to the labelling of Bovine Serum Albumine (BSA) protein [45]. (blue) BSA, (red) BSA + 1 eqt of boranil, (green), BSA +5 eqts of boranil, (purple), BSA + 10 eqts of BSA, (light blue) labeled BSA. Adapted from Reference [45], Copyright 2012 American Chemical Society.

Upon grafting into the protein, a strong luminescence enhancement is observed which the authors attribute to the likely folding of the protein around the dye and the likely location of the boranils complex in hydrophobic pockets.

Red/NIR-emitting fluorescent dyes can also be beneficially used as imaging probes for tissues, cells, or even specifically target given cellular organelles such as mitochondria, lysosomes, or nuclei [13]. Their low-energy fluorescence emission in the so-called therapeutic window is a major asset to enhance imaging resolution owing to a stronger tissue transparency [13]. A NIR-emitting boranil dye with a strong fluorosolvatochromic emission profile has been embedded in Cremophor EL, an amphiphilic co-polymer which allows a good solubility in PBS buffer and a fast and convenient intracellular diffusion in HeLa cells. The cellular uptake and distribution was monitored using fluorescence lifetime imaging microscopy (FLIM) and real-time widefield imaging. It was found that the emission of the dye is strongly influenced by the local environment and that the dye is preferentially internalized in acidic vesicles (Figure 4) [33].

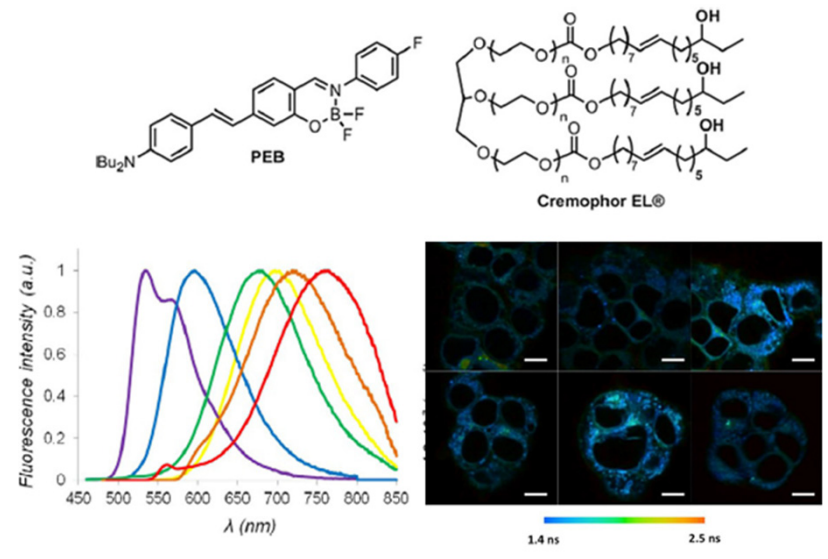

Figure 4. Cellular imaging using fluorescent boranils probes [33]. Emission spectra on the bottom left curves: (purple) cyclohexane, (blue) toluene, (green) THF, (yellow) DCM, (orange) acetone, (red) DMSO. Adapted from Reference [33]. Copyright 2017 John Wiley and Sons. 
Another example involves the incorporation of phenyl rings on the boranil scaffold to act as intramolecular rotors in order to trigger aggregation-induced emission (AIE). AIE or Aggregation-Induced Enhanced Emission (AIEE), stemming from propeller-shaped fluorophores, fully (AIE) or partially (AIEE) quenched in fluid solution but highly emissive at high concentrations in aggregates; these have fueled extensive research in the last decade. This interesting phenomenon allowed overcoming aggregation-caused quenching effect (ACQ), at the origin of the extinction of fluorescence in the solid-state. A strong yellow emission was observed in the aggregated-state, as a consequence of the restrictions of intramolecular rotations. Moreover, this dye shows good biocompatibility and suitable lipophilicity to selectively stain lipid droplets in living cells in fast and wash-free manner, as well as yolk lipids in zebra fish [46].

Other examples of the utilization of the boranil scaffold in biology-related applications include red-emitting phenothiazine-substituted boranils for the selective detection of thiophenol in water samples, in serum, on paper filter strips, and in living cells [47]. In addition, a ratiometric fluorescent probe modulated by ICT and photoinduced electron transfer (PeT) processes was developed for the selective detection and imaging of cysteine, with an excellent selectivity between cysteine, homocysteine, and glutathione due to a very specific conjugate addition-cyclisation reaction [48]. Finally, iodo-functionalized mononuclear or dinuclear boranils complexes showed photosensitized generation of singlet oxygen, due to the stabilization of the triplet state owing to the heavy atom effects. Incorporation of these dyes in polymer films allowed the photosensitized depollution of organic water pollutants [49].

Tetraphenylethylene moieties have been by far the most studied AIE-inducing moiety and they have been grafted onto the scaffold of many fluorescent dyes, including boron complexes such as boranils (Figure 5) [50,51]. These dyes exhibit AIE/AIEE effect in THF/water or $\mathrm{CH}_{3} \mathrm{CN} /$ water mixtures when the water fraction reached 75 to $80 \%$, a classical feature in AIE/AIEE luminescence. Another interesting feature is that these probes showed membrane permeability which shows great potential for application in cellulo. Chiral boranils complexes have also been shown to display AIEE effect leading to a bright emission in the solid-state [52].
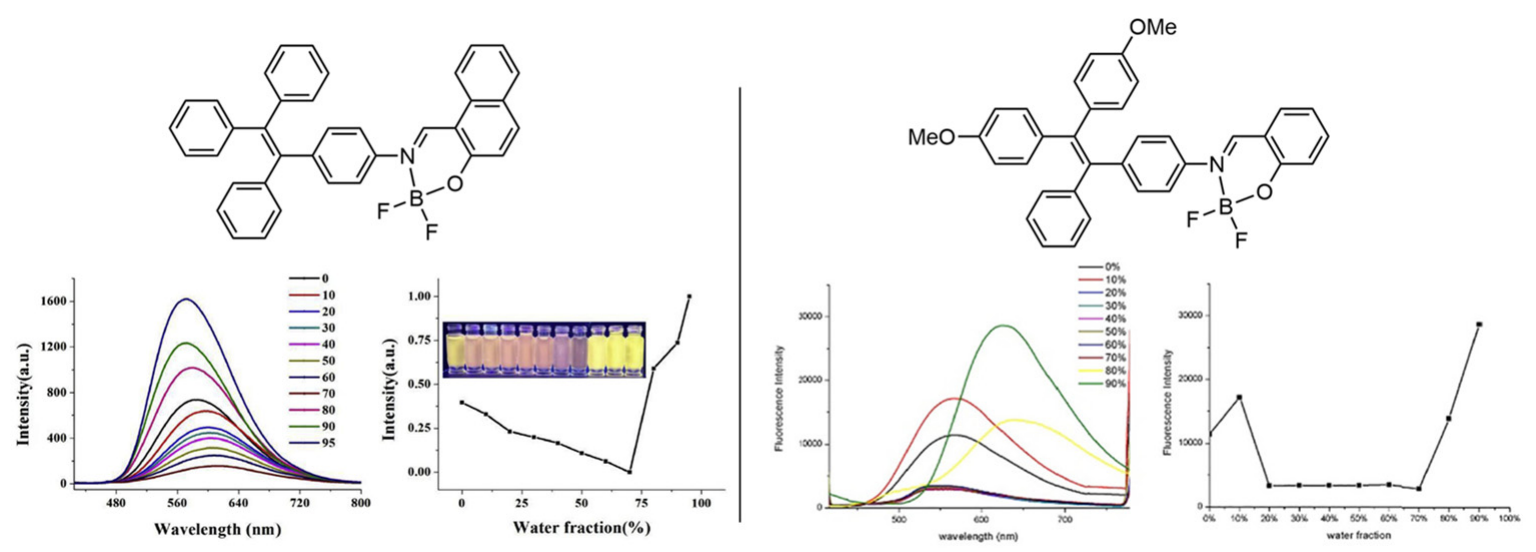

Figure 5. Examples of boranils dyes displaying Aggregation-Induced Emission (AIE) or Aggregation-Induced Enhanced Emission (AIEE) [50,51]. Adapted from Reference [50]. Copyright 2019 Elsevier. Adapted from Reference [51]. Copyright 2018 Elsevier.

Incorporation of Lewis acidic boron mesityl units onto the boranil core led to the development of mechanofluorochromic dyes whose maximum absorption and emission wavelengths can be modified depending on the spacer and the position of functionalization. These compounds exhibit fluorescence variations in response to external stimuli such as mechanical grinding (Figure 6, left) [53]. Lu et al. described a boranil dimer directly linked through central nitrogen atoms with peripheral tert-butyl groups which 
could form organogels in n-hexane. Introduction of a central phenyl ring did not form gels due to strong $\pi-\pi$ interactions but the corresponding boranil complexes exhibited piezofluorochromic behaviors (Figure 6, right) [54]. Blue-green emitting crystals could be ground into yellow emitting amorphous powders and the initial emission can be recovered upon heating. Other mechanofluorochromic examples of boranils include triphenylamine functionalized dyes [55] and units comprised of thiophene and $\alpha$-cyanostilbene [56].

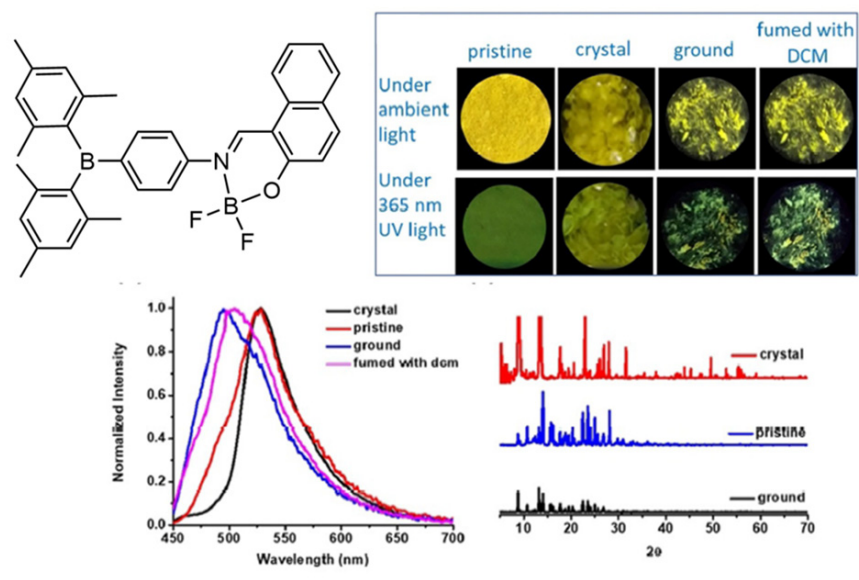

Figure 6. Examples of boranils complexes exhibiting mechanofluorochromic fluorescence emission [53]. Adapted from Reference [53]. Copyright 2020 John Wiley and Sons.

A very recent example by the group of Crassous details the preparation of mono- and di-boranil substituted helicenes, whose enantiomers could be separated using chiral HPLC. Both complexes display circularly polarized fluorescence in solution and in PMMA films (Figure 7) [57].
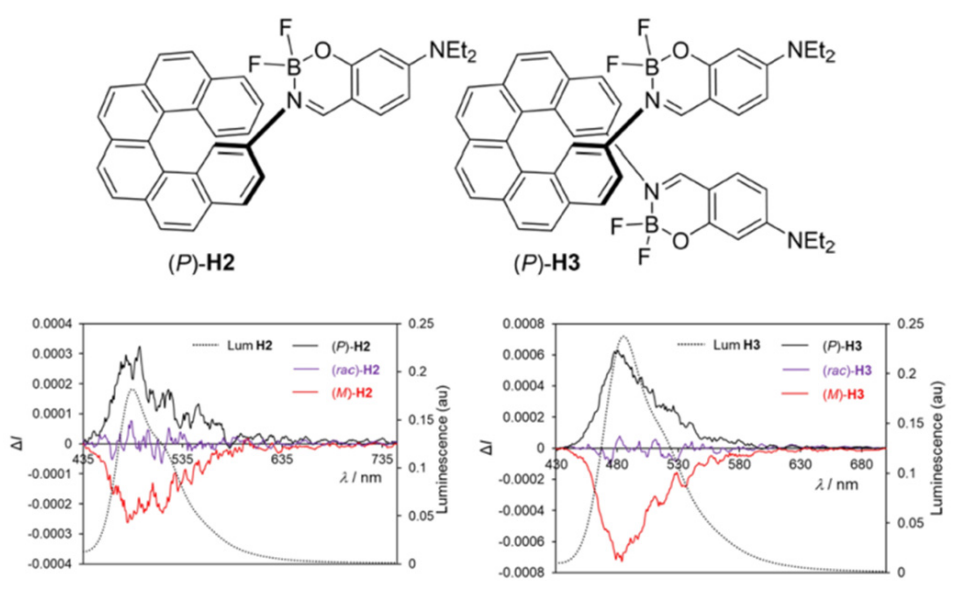

Figure 7. Circularly polarized fluorescent helicene-boranils conjugates [57]. Adapted from Reference [57]. Copyright 2021 John Wiley and Sons.

Other reported applications of boranils dyes include their use as metal-free phosphorescence emitters [58,59]. In particular, phosphorescent organic solid-state laser from a nanowire microcavity of a sulfide-substituted boranil dye enables the observation of triplet emission at $650 \mathrm{~nm}$ under pulsed excitation [59].

There has also been several theoretical works devoted to boranils [60-63]. The most complete methodological study we are aware of, ref [60] demonstrated that the excited states of boranil dyes show various admixtures of cyanine/ICT character depending on the substitution patterns, making them especially challenging for Time-Dependent Density Functional Theory (TD-DFT). In more details, the benchmark performed in that work 
indicates that: (i) a global hybrid functional, with a large share of exact exchange, e.g., M062X, CAM-B3LYP, or B97X-D, is needed to reach accurate simulations of the absorption and fluorescence signatures of boranil dyes; (ii) the selected theoretical solvation model strongly impacts the quality of the simulations. For a typical push-pull boranil, theory allowed to quantify the ICT nature, with a very large increase of the dipole moment upon excitation, as well as a clear ICT from one end of the molecule to another (Figure 8). Likewise, for two dyads, TD-DFT calculations could rationalize why BODIPY-boranil and bis-boranil dyes behaved very differently [60].
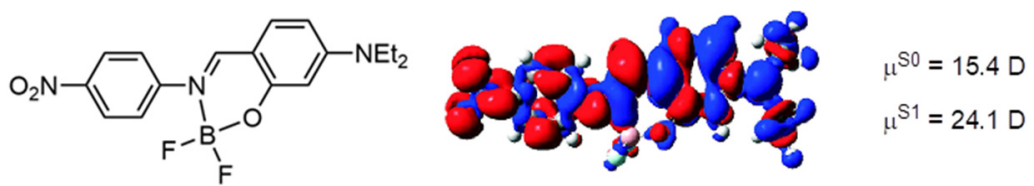

Figure 8. Representation of a typical boranil dye, with its electron density plots (EDD) and computed ground and excited state dipole moments. The level of theory used is PCM-M06-2X/6-31G (d). On the EDD plot, the blue and red lobes respectively represent regions of decrease and increase of electron density upon excitation. Adapted from Reference [60]. Copyright 2013 American Chemical Society.

In 2018, a rather similar computational protocol was used to model the vibrationallyresolved absorption and emission spectra of a more complex boranil derivative synthesized previously [24] (Figure 9) [61]. Besides reproducing the experimental trends, this simulation allowed one to pinpoint the vibrational modes responsible for the shoulder appearing in the experimental fluorescence and phosphorescence spectra. [61] One can also find other theoretical studies discussing infrared and NMR signatures of boranils $[62,63]$.

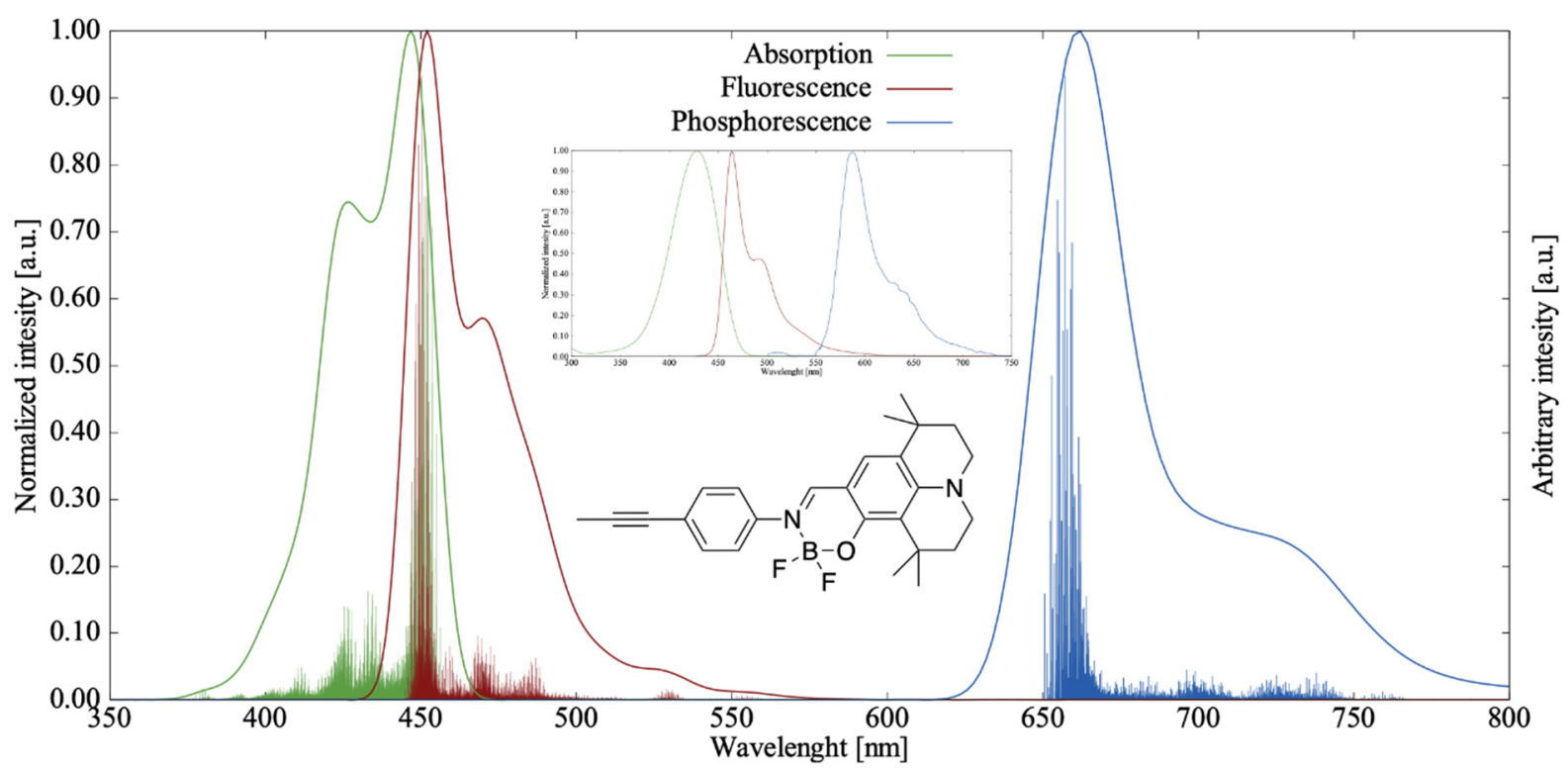

Figure 9. Computed vibronic spectra of the displayed boranil. The green, red, and blue curves represent the absorption, fluorescence, and phosphorescence spectra simulated in the basis of the individual vibronic peaks (sticks). The inset is the experimental measurement taken from Reference [39]. Adapted from Reference [61] with permission from the PCCP Owner Societies.

\section{Conclusions}

In conclusion, this small account summarizes recent advances concerning the design and chemical engineering around boron complexes newcomers called boranil and their reported applications. Compared to their BODIPY parents, these fluorescent dyes display 
attractive emission intensity in the solid-state, enhanced Stokes shift, and easier synthetic pathways. Currently, due to their intrinsic asymmetric molecular structures, many boranil dyes display ICT-driven emission, highly dependent to solvatation which tend to be quenched in polar protic environment. Further studies currently aim at improving their stability and fluorescence intensity in solution and diversify the range of applications.

Shifting the emission wavelength of the boranil core towards the NIR region while keeping strong emission intensity remains a challenge which needs to be tackled to envision applications in biotechnology. Moreover, some boranil dyes show interesting AIE properties which represent an attractive approach for the engineering of high luminous organic nanoparticles and solid emitters. Future perspective also includes the development of white-light-emitting materials, based on boranils.

Author Contributions: Writing-original draft preparation, J.M., G.U., D.J.; writing-review and editing, J.M., G.U., D.J. All authors have read and agreed to the published version of the manuscript.

Funding: This research received no external funding.

Informed Consent Statement: Not applicable.

Conflicts of Interest: The authors declare no conflict of interest.

\section{References}

1. Forrest, S.R.; Thompson, M.E. Organic Electronics and Optoelectronics. Chem. Rev. 2007, 107, 923. [CrossRef]

2. Gong, J.; Sumathy, K.; Qiao, Q.; Zhou, Z. Review on dye-sensitized solar cells (DSSCs): Advanced techniques and research trends. Renew. Sustain. Energy Rev. 2017, 68, 234. [CrossRef]

3. Gsänger, M.; Bialas, D.; Huang, L.; Stolte, M.; Würthner, F. Organic Semiconductors based on Dyes and Color Pigments. Adv. Mater. 2016, 28, 3615.

4. Jun, J.V.; Chenoweth, D.M.; Petersson, E.J. Rational design of small molecule fluorescent probes for biological applications. Org. Biomol. Chem. 2020, 18, 5747. [CrossRef] [PubMed]

5. Park, S.-H.; Kwon, N.; Lee, J.-H.; Yoon, J.; Shin, I. Synthetic ratiometric fluorescent probes for detection of ions. Chem. Soc. Rev. 2020, 49, 143. [CrossRef]

6. Singh, H.; Tiwari, K.; Tiwari, R.; Pramanik, S.K.; Das, A. Small Molecule as Fluorescent Probes for Monitoring Intracellular Enzymatic Transformations. Chem. Rev. 2019, 119, 11718. [CrossRef] [PubMed]

7. Anthony, J.E. Functionalized Acenes and Heteroacenes for Organic Electronics. Chem. Rev. 2006, 106, 5028. [CrossRef] [PubMed]

8. Wasielewski, M.R. Photoinduced electron transfer in supramolecular systems for artificial photosynthesis. Chem. Rev. 1992, 92, 435. [CrossRef]

9. Lee, H.; Hong, K.-I.; Jang, W.-D. Design and applications of molecular probes containing porphyrin derivatives. Coord. Chem. Rev. 2018, 354, 46. [CrossRef]

10. Tasior, M.; Kim, D.; Singha, S.; Krzeszewski, M.; Ahn, K.H.; Gryko, D.T. $\pi$-Expanded coumarins: Synthesis, optical properties and applications. J. Mater. Chem. C 2015, 3, 1421. [CrossRef]

11. Beija, M.; Afonso, C.A.M.; Martinho, J.M.G. Synthesis and applications of Rhodamine derivatives as fluorescent probes. Chem. Soc. Rev. 2009, 38, 2410. [CrossRef]

12. Mishra, A.; Behera, R.K.; Behera, P.K.; Mishra, B.K.; Behera, G.B. Cyanines during the 1990s: A Review. Chem. Rev. 2000, 100, 1973. [CrossRef] [PubMed]

13. Khopkar, S.; Shankarling, G. Synthesis, photophysical properties and applications of NIR absorbing unsymmetrical squaraines: A review. Dyes Pigm. 2019, 170, 107645. [CrossRef]

14. Chen, L.; Lia, C.; Müllen, K. Beyond perylene diimides: Synthesis, assembly and function of higher rylene chromophores. J. Mater. Chem. C 2014, 2, 1938. [CrossRef]

15. Ulrich, G.; Ziessel, R.; Harriman, A. The Chemistry of Fluorescent Bodipy Dyes: Versatility Unsurpassed. Angew. Chem. Int. Ed. 2008, 47, 1184. [CrossRef] [PubMed]

16. Xiao, S.; Cao, Q.; Dan, F. Solid-Emissive BODIPY Derivatives: Design, Synthesis and Applications. Curr. Org. Chem. 2012, 16, 2970. [CrossRef]

17. Lu, H.; Mack, J.; Yang, Y.; Shen, Z. Structural modification strategies for the rational design of red/NIR region BODIPYs. Chem. Soc. Rev. 2014, 43, 4778. [CrossRef]

18. Wang, J.; Boens, N.; Jiao, L.; Hao, E. Aromatic [b]-fused BODIPY dyes as promising near-infrared dyes. Org. Biomol. Chem. 2020, 18, 4135. [CrossRef]

19. Ulrich, G.; Goze, C.; Guardigli, M.; Roda, A.; Ziessel, R. Pyrromethene Dialkynyl Borane Complexes for “Cascatelle” Energy Transfer and Protein Labeling. Angew. Chem. Int. Ed. 2005, 44, 3694. [CrossRef] 
20. Zhao, J.; Ji, S.; Chen, Y.; Guo, H.; Yang, P. Excited state intramolecular proton transfer (ESIPT): From principal photophysics to the development of new chromophores and applications in fluorescent molecular probes and luminescent materials. Phys. Chem. Chem. Phys. 2012, 14, 8803. [CrossRef]

21. Massue, J.; Jacquemin, D.; Ulrich, G. Molecular Engineering of Excited-state Intramolecular Proton Transfer (ESIPT) Dual and Triple Emitters. Chem. Lett. 2018, 47, 1083. [CrossRef]

22. Frath, D.; Massue, J.; Ulrich, G.; Ziessel, R. Luminescent materials: Locking $\pi$-conjugated and heterocyclic ligands with boron(III). Angew. Chem. Int. Ed. 2014, 53, 2290. [CrossRef] [PubMed]

23. Jędrzejewska, B.; Zakrzewska, A.; Mloston, G.; Budzák, S.; Mroczynska, K.; Grabarz, A.M.; Kaczorowska, M.A.; Jacquemin, D.; Osmiałowski, B. Synthesis and Photophysical Properties of Novel Donor-Acceptor N-(Pyridin-2-yl)-Substituted Benzo(thio)amides and Their Difluoroboranyl Derivatives. J. Phys. Chem. A 2016, 120, 4116. [CrossRef] [PubMed]

24. Grabarz, A.M.; Laurent, A.D.; Jedrzejewska, B.; Zakrzewska, A.; Jacquemin, D.; Osmiałowski, B. The Influence of the $\pi$ Conjugated Spacer on Photophysical Properties of Difluoroboranyls Derived from Amides Carrying a Donor Group. J. Org. Chem. 2016, 81, 2280. [CrossRef] [PubMed]

25. Massue, J.; Frath, D.; Ulrich, G.; Retailleau, P.; Ziessel, R. Synthesis of Luminescent 2-(2-Hydroxyphenyl)benzoxazole (HBO) Borate Complexes. Org. Lett. 2012, 14, 230. [CrossRef]

26. Massue, J.; Frath, D.; Retailleau, P.; Ulrich, G.; Ziessel, R. Synthesis of Luminescent Ethynyl-Extended Regioisomers of Borate Complexes Based on 2-(2'-Hydroxyphenyl)benzoxazole. Chem. Eur. J. 2013, 19, 5375. [CrossRef]

27. Benelhadj, K.; Massue, J.; Retailleau, P.; Ulrich, G.; Ziessel, R. 2-(2-Hydroxyphenyl)benzimidazole and 9,10-Phenanthroimidazole Chelates and Borate Complexes: Solution- and Solid-State Emitters. Org. Lett. 2013, 15, 2918. [CrossRef]

28. Potopnyk, M.A.; Volyniuk, D.; Luboradzki, R.; Ceborska, M.; Hladka, I.; Danyliv, Y.; Grazulevicius, J.V. Organolithium-Mediated Postfunctionalization of Thiazolo[3,2- c][1,3,5,2]oxadiazaborinine Fluorescent Dyes. J. Org. Chem. 2020, 85, 6060. [CrossRef]

29. Taguchi, J.; Matsuura, S.; Seki, T.; Ito, H. Synthesis and Tunable Optical Properties of C,N-Chelated Borate Luminophores Derived from Potassium Acyltrifluoroborates. Chem. Eur. J. 2020, 26, 2450. [CrossRef]

30. Más-Montoya, M.; Montenegro, M.F.; Ferao, A.E.; Tárraga, A.; Rodríguez-López, J.N.; Curiel, D. Rigid $\pi$-Extended Boron Difluoride Complex with Mega-Stokes Shift for Bioimaging. Org. Lett. 2020, 22, 3356. [CrossRef]

31. Frath, D.; Azizi, S.; Ulrich, G.; Retailleau, P.; Ziessel, R. Facile Synthesis of Highly Fluorescent Boranil Complexes. Org. Lett. 2011, 13, 3414. [CrossRef] [PubMed]

32. Ren, X.; Zhang, F.; Luo, H.; Liao, L.; Song, X.; Chen, W. Red-emitting boron difluoride complexes with a mega-large Stokes shift and unexpectedly high fluorescence quantum yield. Chem. Commun. 2020, 56, 2159. [CrossRef]

33. Frath, D.; Didier, P.; Mély, Y.; Massue, J.; Ulrich, G. Vectorization and Intracellular Distribution of a Two-Photon-Absorbing, Near-Infrared-Emitting $\pi$-Extended Boranil Dye. ChemPhotoChem. 2017, 1, 109. [CrossRef]

34. Benelhadj, K.; Massue, J.; Retailleau, P.; Chibani, S.; le Guennic, B.; Jacquemin, D.; Ziessel, R.; Ulrich, G. Solution- and Solid-State Luminescent Borate Complexes Based on a Substituted $\pi$-Conjugated 2-( $6^{\prime}$-Hydroxy-5'-benzofuryl) Scaffold. Eur. J. Org. Chem. 2014, 2014, 7156-7164. [CrossRef]

35. Urban, M.; Durka, K.; Jankowski, P.; Serwatowski, J.; Lulinski, S. Highly Fluorescent Red-Light Emitting Bis(boranils) Based on Naphthalene Backbone. J. Org. Chem. 2017, 82, 8234. [CrossRef]

36. Frath, D.; Benelhadj, K.; Munch, M.; Massue, J.; Ulrich, G. Polyanils and Polyboranils: Synthesis, Optical Properties, and Aggregation-Induced Emission. J. Org. Chem. 2016, 81, 9658. [CrossRef]

37. Crandall, L.A.; Dawadi, M.B.; Burrell, T.; Odoom, A.; Ziegler, C.J. Structure and electronics in dimeric boron $\pi$ expanded azine and salphen complexes. Photochem. Photobiol. Sci. 2017, 16, 627. [CrossRef]

38. Dobkowski, J.; Wnuk, P.; Buczyńska, J.; Pszona, M.; Orzanowska, G.; Frath, D.; Ulrich, G.; Massue, J.; Mosquera-Vázquez, S.; Vauthey, E.; et al. Substituent and Solvent Effects on the Excited State Deactivation Channels in Anils and Boranils. Chem. Eur. J. 2015, 21, 1312. [CrossRef]

39. Nano, A.; Gullo, M.P.; Ventura, B.; Armaroli, N.; Barbieri, A.; Ziessel, R. Panchromatic luminescence from julolidine dyes exhibiting excited state intramolecular proton transfer. Chem. Commun. 2015, 51, 3351. [CrossRef]

40. Suresh, D.; Gomes, C.S.B.; Lopes, P.S.; Figueira, C.A.; Ferreira, B.; Gomes, P.T.; di Paolo, R.E.; Maçanita, A.L.; Duarte, M.T.; Charas, A.; et al. Luminescent Di- and Trinuclear Boron Complexes Based on Aromatic Iminopyrrolyl Spacer Ligands: Synthesis, Characterization, and Application in OLEDs. Chem. Eur. J. 2015, 21, 9133. [CrossRef]

41. Li, D.; Zhang, Z.; Zhao, S.; Wang, Y.; Zhang, H. Diboron-containing fluorophores with extended ladder-type $\pi$-conjugated skeletons. Dalton Trans. 2011, 40, 1279. [CrossRef]

42. Dhanunjayarao, K.; Mukundam, V.; Ramesh, M.; Venkatasubbaiah, K. Synthesis and Optical Properties of Salicylaldimine-Based Diboron Complexes. Eur. J. Inorg. Chem. 2014, 3, 539. [CrossRef]

43. Wesela-Bauman, G.; Urban, M.; Lulinski, S.; Serwatowski, J.; Wozniak, K. Tuning of the colour and chemical stability of model boranils: A strong effect of structural modifications. Org. Biomol. Chem. 2015, 13, 3268. [CrossRef] [PubMed]

44. Urban, M.; Durka, K.; Gorka, P.; Wiosna-Salyga, G.; Nawara, K.; Jankowski, P.; Lulinski, S. The effect of locking $\pi$-conjugation in organoboron moieties in the structures of luminescent tetracoordinate boron complexes. Dalton Trans. 2019, 48, 8642. [CrossRef]

45. Frath, D.; Azizi, S.; Ulrich, G.; Ziessel, R. Chemistry on Boranils: An Entry to Functionalized Fluorescent Dyes. Org. Lett. 2012, 14, 4774. [CrossRef] [PubMed] 
46. Zhao, N.; Ma, C.; Yang, W.; Yin, W.; Wei, J.; Li, N. Facile construction of boranil complexes with aggregation-induced emission characteristics and their specific lipid droplet imaging applications. Chem. Commun. 2019, 55, 8494. [CrossRef]

47. Chen, W.; Zhu, L.; Hao, Y.; Yue, X.; Cai, J.; Xiao, Q.; Huang, S.; Sheng, J.; Song, X. Detection of thiophenol in buffer, in serum, on filter paper strip, and in living cells using a red-emitting amino phenothiazine boranil based fluorescent probe with a large Stokes shift. Tetrahedron 2017, 73, 4529. [CrossRef]

48. Zhu, D.; Yan, X.; Ren, A.; Cai, W.; Duan, Z.; Luo, Y. Modulation of ICT and PET processes in boranil derivatives: A ratiometric fluorescent probe for imaging of cysteine. Anal. Methods 2019, 11, 2579. [CrossRef]

49. Shah, S.; Bajaj, A.; Shibu, A.; Ali, M.E.; Neelakandan, P.P. Iodo-Functionalized Salicylideneimine-Boron Complexes: Synthesis and Photosensitized Degradation of Organic Water Pollutants. Chem. Eur. J. 2018, 24, 18788. [CrossRef]

50. Sun, T.; Cheng, D.; Chai, Y.; Gong, J.; Sun, M.; Zhao, F. High contrast mechanofluorochromic behavior of new tetraphenylethenebased Schiff base derivatives. Dyes Pigm. 2019, 170, 107619. [CrossRef]

51. Chen, S.; Qiu, R.; Yu, Q.; Zhang, X.; Wei, M.; Dai, Z. Boranil dyes bearing tetraphenylethene: Synthesis, AIE/AIEE effect properties, $\mathrm{pH}$ sensitive properties and application in live cell imaging. Tetrahedron Lett. 2018, 59, 2671. [CrossRef]

52. Vaz, P.A.A.M.; Rocha, J.; Silva, A.M.S.; Guieu, S. Aggregation-induced emission enhancement of chiral boranils. New J. Chem. 2018, 42, 18166. [CrossRef]

53. Nandi, R.P.; Sudhakar, P.; Kalluvettukuzhy, N.K.; Thilagar, P. Triarylborane-Appended Anils and Boranils: Solid-State Emission, Mechanofluorochromism, and Phosphorescence. Chem. Eur. J. 2020, 26, 16306. [CrossRef] [PubMed]

54. Gong, P.; Yang, H.; Sun, J.; Zhang, Z.; Sun, J.; Xue, P.; Lu, R. Salicylaldimine difluoroboron complexes containing tert-butyl groups: Nontraditional $\pi$-gelator and piezofluorochromic compounds. J. Mater. Chem. C 2015, 3, 10302. [CrossRef]

55. Sun, J.; Yang, H.; Simalou, O.; Lv, K.; Zhai, L.; Zhao, J.; Lu, R. Mechanofluorochromic behaviors of triphenylamine functionalized salicylaldimine difluoroboron complexes. New J. Chem. 2019, 43, 10134. [CrossRef]

56. Fang, W.; Zhang, Y.; Zhang, G.; Kong, L.; Yang, L.; Yang, J. Multi-stimuli-responsive fluorescence of a highly emissive difluoroboron complex in both solution and solid states. Cryst. Eng. Comm. 2017, 19, 1294. [CrossRef]

57. Macé, A.; Hamrouni, K.; Gauthier, E.S.; Jean, M.; Vanthuyne, N.; Frédéric, L.; Pieters, G.; Caytan, E.; Roisnel, T.; Aloui, F.; et al. Circularly Polarized Fluorescent Helicene-Boranils: Synthesis, Photophysical and Chiroptical Properties. Chem. Eur. J. 2021, 27, 7959. [CrossRef] [PubMed]

58. Koch, M.; Perumal, K.; Blacque, O.; Garg, J.A.; Saiganesh, R.; Kabilan, S.; Balasubramanian, K.K.; Venkatesan, K. Metal-free triplet phosphors with high emission efficiency and high tenability. Angew. Chem. Int. Ed. 2014, 53, 6378. [CrossRef]

59. Yu, Z.; Wu, Y.; Xiao, L.; Chen, J.; Liao, Q.; Yao, J.; Fu, H. Organic Phosphorescence Nanowire Lasers. J. Am. Chem. Soc. 2017, 139, 6376. [CrossRef] [PubMed]

60. Chibani, S.; Charaf-Eddin, A.; le Guennic, B.; Jacquemin, D. Boranil and related NBO Dyes: Insights from Theory. J. Chem. Theory Comput. 2013, 9, 3127. [CrossRef] [PubMed]

61. Budzak, S.; Jacquemin, D. Excited state intramolecular proton transfer in julolidine derivatives: An ab initio study. Phys. Chem. Chem. Phys. 2018, 20, 25031. [CrossRef] [PubMed]

62. Chaabene, M.; Agren, S.; Allouche, A.R.; Chaâbane, R.B.; Lahcinie, M.; Baouab, M.H.V. Theoretical and experimental investigations of complexation with $\mathrm{BF}_{3} . \mathrm{Et}_{2} \mathrm{O}$ effects on electronic structures, energies and photophysical properties of Anil and tetraphenyl (hydroxyl) imidazole. Appl. Organomet. Chem. 2019, 33, e5218. [CrossRef]

63. Agren, S.; Chaabene, M.; Allouche, A.R.; Chaâbane, R.B.; Lahcinie, M.; Baouab, M.H.V. Blue Highly Fluorescent Boranil Derived from Anil Ligand: Synthesis, Characterization, Experimental and Theoretical Evaluation of Solvent Effect on Structures and Photophysical Properties. Appl. Organomet. Chem. 2020, 34, e5764. [CrossRef] 